\title{
Chloride Content of Dissolver Solution from Rocky Flats Scrub Alloy Ninth and Tenth Campaigns Following Head End Treatment
}

by

H. P. Holcomb

E. I. du Pont de Nemours and Company

Savannah River Site

Aiken, South Carolina 29808

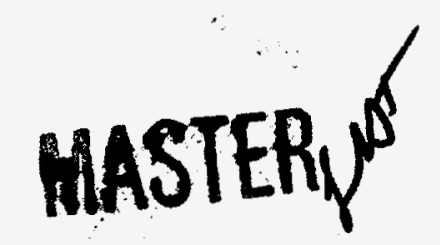

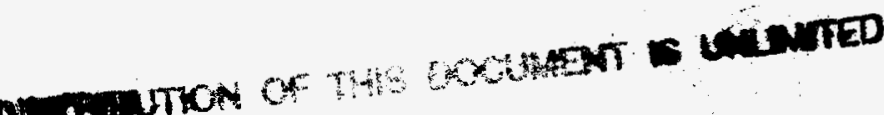

\section{DOE Contract No.}

This paper was prepared in connection with work done under the above contract number with the U. S. Department of Energy. By acceptance of this paper, the publisher and/or recipient acknowledges the U.S. Government's right to retain a nonexclusive, royalty-free license in and to any copyright covering this paper, along with the right to reproduce and to authorize others to reproduce all or part of the copyrighted paper. 


\section{DISCLAIMER}

This report was prepared as an account of work sponsored by an agency of the United States Government. Neither the United States Government nor any agency thereof, nor any of their employees, makes any warranty, express or implied, or assumes any legal liability or responsibility for the accuracy, completeness, or usefulness of any information, apparatus, product, or process disclosed, or represents that its use would not infringe privately owned rights. Reference herein to any specific commercial product, process, or service by trade name, trademark, manufacturer, or otherwise does not necessarily constitute or imply its endorsement, recommendation, or favoring by the United States Government or any agency thereof. The views and opinions of authors expressed herein do not necessarily state or reflect those of the United States Government or any agency thereof.

This report has been reproduced directly from the best available copy.

Available to DOE and DOE contractors from the Office of Scientific and Technical Information, P. O. Box 62, Oak Ridge, TN 37831; prices available from (423) 576-8401.

Available to the public from the National Technical Information Service, U. S. Department of Commerce, 5285 Port Royal Road, Springfield, VA 22161. 


\section{DISCLAIMER}

Portions of this document may be illegible in electronic image products. Images are produced from the best available original document. 
DPSPU-88-272-33

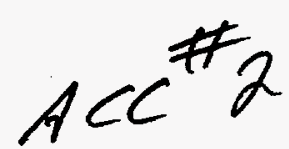

44004

chloride

March 8, 1988

TO: L. B. CURTIS, 221-F - D. F. CHOSTNER, 221-F

FROM: н. Р. ноLсомв, 772-F HPH INFORMATION ONLY

CHLORIDE CONTENT OF DISSOLVER SOLUTION FROM ROCKY FLATS SCRUB ALLOY NINTH AND TENTH CAMPAIGNS FOLLOWING HEAD END TREATMENT

INTRODUCTION AND SUMMARY

F-Canyon continues to obtain excellent chloride removal from Rocky Flats Scrub Alloy (RFSA) dissolver solution during head end treatment. One single batch of solution from the ninth RFSA campaign, dissolved in January and February of this year, and two batches from the tenth campaign, dissolved in February, have been successfully processed. Following dissolution in Tank 6.4D, chloride was precipitated with mercurous ion added as the nitrate. The precipitate, $\mathrm{Hg}_{2} \mathrm{Cl}_{2}$, was concurrently removed with the gelatin floc via centrifugation.

For each of these three batches processed, a set of duplicate samples was obtained from Tank 11.2 or from Tank 13.3, containing the head end product. The samples were preanalyzed by Laboratories Department for density and acidity to ensure them to be representative of the tank's contents prior to chloride analysis by the Separations Technology Laboratory.

For the single batch of material processed from the ninth campaign, the head end product contained $37 \mathrm{ppm}$ ( $\mu \mathrm{g} / \mathrm{mL}$ ) chloride, a DF of 36. Relative standard deviation of the measurement was $\pm 5 \mathrm{ppm}$ $(n=4)$ for a precision of $\pm 14 \%$.

The dissolver solution from the tenth campaign contained significantly less chloride, only $870 \mathrm{ppm}$, than those previously. Due to volume, it was processed through head end in two batches. For the first batch, the head end product contained $28 \mathrm{ppm}$ chloride with a relative standard deviation of $\pm 3 \mathrm{ppm}$, or $\pm 11 \%$. The product from the second head end batch had $40 \mathrm{ppm}$ chloride with a relative standard deviation of $\pm 3 \mathrm{ppm}$, or $\pm 8 \%$. DFs were 31 and 22 , respectively. 
DPSPU-88-272-33

L. B. CURTIS - D. F. CHOSTNER

Page 2

March 8, 1988

EXPERIMENTAL

Samples Analyzed

For the single batch from the ninth campaign, a pair of samples, designated as Laboratories $\# 31445$ and 31446 , from Tank 13.3, were analyzed. The chloride value for this solution, diluted somewhat from the actual head end product in Tank 11.2, was used by F-Canyon Sep Tech to backcalculate the chloride value of the solution in Tank 11.2.

For the first batch from the tenth campaign, samples $\# 47241$ and 47242 were analyzed; for the second batch, $\$$ 俉7291 and 47293 .

Agreement between acidity and density values between each pair was excellent. Therefore, the samples were considered to be representative of the tank's contents.

All samples were very clear in appearance and light tannish-brown in color. No solids were noted.

Analysis of Chloride

The procedurel employed to determine the low values of chloride in the high alpha solutions was also used for the previous RFSA campaigns, except for the first. A visual turbidity comparison was used for that campaign since our improved method had not been developed. The newer analytical technique employs an instrumental measurement of turbidity formed when silver ion reacts with residual chloride in the sample aliquots. Sample pretreatment negated interferences by other ions, principally $\mathrm{Al}^{+3}$ and $\mathrm{Hg}^{+2}$. The latter, in solution, forms a very strong covalent bond with chloride. This compound ionized only to a very small extent and, without pretreatment, can be the cause of low chloride results from usual analytical procedures.

Standards, prepared in a radioactively cold matrix closely simulating that of the RFSA solution and containing known quantities of chloride, were concurrently analyzed in like manner to provide a working curve of turbidity versus total chloride in solution.

$\underline{\text { Results }}$

Individual values obtained for the chloride content of duplicate $1-\mathrm{mL}$ aliquots taken from each product tank are shown in Table 1. Also given is the average of the four results, reported as the analysis value, and the relative standard deviation for the average. 
DPSPU-88-272-33

L. B. CURTIS - D. F. CHOSTNER

Page 3

March 8, 1988

TABLE 1

CHLORIDE CONTENT OF RFSA DISSOLVER SOLUTIONS FOLLOWING HEAD END

$\mathrm{CI}^{-}$

Run 1FDRFS1-3, Ninth Campaign $\mathrm{ppm}(\mu \mathrm{g} / \mathrm{mL})$

Tank 13.3, \#31445

Aliquot $\# 1$

32

Aliquot \#2

37

Tank 13.3, 非31446

Aliquot 非 1

Aliquot $\# 2$

Average $(n=4) \quad 33$

Rel. Std. Dev. $5( \pm 15 \%)$

Average normalized to Tank 11.2 contents $=37 \mathrm{ppm}$.

Run 2FDRF1-2 非1 - 1st Batch, 10th Campaign

Tank 11.2, 非 47241

Aliquot 非 32

Aliquot 非 29

Tank 11.2, \#47242

Aliquot 非 27

Aliquot 非 24

Average $\quad(\mathrm{n}=4) \quad 28$

Rel. Std. Dev. $3( \pm 11 \%)$

Run 2FDRF1-2 非 - 2nd Batch, 10th Campaign

Tank 11.2, 非7291

Aliquot 非 42

Aliquot \#2 37

Tank 11.2, 非47293

Aliquot 非

Aliquot 非 42

Average $(n=4) \quad 40$

Rel. Std. Dev. $3( \pm 8 \%)$ 
DPSPU $-88-272-33$

L. B. CURTIS - D. F. CHOSTNER

Page 4

March 8, 1988

\section{DISCUSSION}

Previous work 2 at SRL by R. S. Ondrejcin indicated that in order to protect downstream canyon equipment from chloride attack, the chloride content of RFSA solutions should be less than $100 \mathrm{ppm}$. All batches from these two RFSA campaigns meet this criterion.

For the ninth campaign, based on Laboratories' value of $1350 \mathrm{ppm}$ $(0.038 \mathrm{M})$ chloride in the material in Tank 10.2 prior to head end treatment, a $\mathrm{Cl}^{-} \mathrm{DF}$ of 37 in Tank 11.2 was obtained.

For the tenth campaign, based on Laboratories' value of $870 \mathrm{ppm}$ $(0.0245 \mathrm{M})$ chloride in Tank 10.2 prior to head end, a C1- DF of 31 was obtained for the first batch, and 22 for the second batch.

Table 2 summarizes the chloride content of the solutions before and after head end treatment, for those RFSA campaigns for which the turbidimetric technique was used to determine the chloride following head end. Pairs of numbers represent different batches of the same campaign.

TABLE 2

CHLORIDE REMOVAL SUMMARY FOR RFSA CAMPAIGNS

\begin{tabular}{|c|c|c|c|}
\hline RFSA Campaign & $\begin{array}{l}\text { Ppm } \mathrm{Cl}^{-} \text {Prior } \\
\text { To Head End } \\
\end{array}$ & $\begin{array}{l}\text { ppm } \mathrm{Cl}^{-} \text {After } \\
\text { Head End }\end{array}$ & Chloride DF \\
\hline 2nd & 1600 & 75 & 21 \\
\hline $3 \mathrm{rd}$ & 1000 & 23 & 43 \\
\hline 4 th & $1890-1235$ & $75-45$ & $25-27$ \\
\hline 5 th & 2930 (Avg) & 62 (Avg) & 47 \\
\hline $6 \mathrm{th}$ & 1525 (Avg) & 74 (Avg) & 21 \\
\hline 7 th & $1030-850$ & $39-24$ & $26-35$ \\
\hline 8 th & 1240 & 26 & 48 \\
\hline 9 th & 1350 & 37 & 36 \\
\hline 10 th & 870 & $28-40$ & $31-22$ \\
\hline
\end{tabular}

These summary data show that the DFs obtained for chloride removal across head end for the ninth and tenth campaigns are about average, but quite acceptable. Also, consideration must be given that prior to head end treatment, the chloride content of the tenth campaign was the second lowest yet. Thus, Rocky Flats is doing a good job in removing surface salt from the alloy buttons shipped to SRP. 
DPSPU-88-272-33

L. B. CURTIS - D. F. CHOSTNER

Page 5

March 8, 1988

\section{REFERENCES}

1. DPSPU-84-272-113, Determination of Low Chloride Values in Rocky Flats Scrub Alloy Solutions and Other Complex Matrices, H. P. Holcomb to J. T. Buckner, Jr., November 29, 1984.

2. Excerpt from talk, "Corrosion Study for Rocky Flats Scrub Alloy Program", by R. S. Ondrejcin, SRL, Dec. 2, 1983.

$\mathrm{HPH} / \mathrm{h}$ 